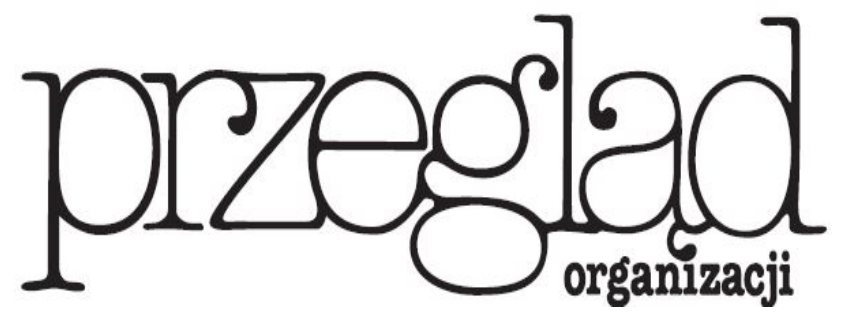

Miesięcznik TNOiK Założył Karol Adamiecki w 1926 r.

\title{
POPULARYZACJA BADAŃ W ZAKRESIE ZARZADZZANIA PROJEKTAMI - WYNIKI BADAŃ BIBLIOMETRYCZNYCH
}

https://doi.org/10.33141/po.2019.03.05

\section{Izabela Konieczna}

\section{Wprowadzenie}

$Z^{2}$ arządzanie projektem jest wyspecjalizowanym obszarem zarządzania, który rozwinął się w celu koordynowania i kontrolowania niektórych złożonych działań nowoczesnego przemysłu (Prabhakar, 2008, s. 5). Zastosowania zarządzania projektem do 1950 roku koncentrowały się na kosztach, harmonogramie i parametrach technicznych, ale brakowało im formalnej definicji i objęcia koncepcji i procesów zarządzania w sposób zintegrowany (Cleland, Gareis, 2006, s. 1-4). Od tego czasu zarządzanie projektem ewoluowało i stało się odrębną dziedziną wiedzy praktycznej i naukowej, posiadającą odrębny
Przegląd Organizacji, Nr 3 (950), 2019, ss. 27-32 www.przegladorganizacji.pl OTowarzystwo Naukowe Organizacji i Kierownictwa (TNOiK)

przedmiot badań, własne podstawy teoretyczne, stosującą specyficzne metody badawcze (Trocki, Bukłaha, 2016, s. 9). Zarządzanie projektem przekształciło się w główne ramię całej dyscypliny nauk o zarządzaniu i wygenerowało kilka ścieżek wiedzy akademickiej oraz wiele strumieni metodologii i najlepszych rozwiązań stosowanych przez praktyków (Johnson i in., 2015, s. 153).

Celami artykułu są określenie zmian popularności tematyki zarządzania projektami wśród badaczy oraz wskazanie, w których czasopismach najczęściej są publikowane badania w przedmiotowym obszarze. Realizacja celów zo- 
stała oparta na przeglądzie wybranych baz naukowych, takich jak: Scopus, Web of Science, Ebsco i Wiley-Blackwell.

\section{Analiza liczby publikacji dotyczących zarządzania projektami}

W celu sprawdzenia liczby publikacji dotyczących zarzadzania projektami przeprowadzono analize wybranych baz naukowych. Jako kryterium wyszukiwania przyjęto występowanie całej frazy „project management”.

1. Baza Scopus - po raz pierwszy fraza „project management" znalazła się w słowach kluczowych w publikacji z 1942 roku pt. Automobile Engineering Organization and Procedure (Paton i in., 1942, s. 439-443+464). Począwszy od lat 60. XX wieku fraza ta zaczęła pojawiać się w tytułach publikacji. Od tego okresu uwidocznił się wyraźny wzrost zainteresowania tym zagadnieniem, co przełożyło się na liczbę publikacji w poszczególnych okresach poddanych analizie. Pierwszym artykułem, który w tytule miał frazę "project management”, był artykuł pt. The Martin Company's Project Management Method (Bowen, 1961), opublikowany w 1961 roku. $\mathrm{W}$ streszczeniu pojęcie to pojawiło się po raz pierwszy w 1960 roku w publikacji pt. The Application of Closed-Loop Techniques to Engineering Project Planning (Haine, Lob, 1960, s. 96-103). Począwszy od lat 60. XX wieku do końca 2018 roku frazę „project management" posiadało ponad 7100 publikacji w tytule, ponad 90 tysięcy w słowach kluczowych i ponad 22 tysiące w streszczeniu. Rozkład liczby publikacji z podziałem na posiadanie frazy „project management” $\mathrm{w}$ tytule, słowach kluczowych i streszczeniu znajduje się na rysunku 1. Wynika z niego, że najwięcej publikacji miało tę frazę w słowach kluczowych, a najmniej w tytule. Jednocześnie w ostatnich latach uwidacznia się tendencja wzrostowa liczby publikacji posiadających tę frazę w tytule i streszczeniu przy jednoczesnym spadku liczby publikacji z tą frazą w słowach kluczowych.

2. Baza Web of Science - ze względu na brak możliwości przeszukania liczby publikacji, biorąc pod uwagę słowa kluczowe i streszczenie, ograniczono analizę do tytułu. Pierwsza publikacja $\mathrm{z}$ frazą „project management” $\mathrm{w}$ tej bazie pochodzi z roku 1962 i nosi tytuł The Role of Project-management in Scientific Manufacturing (Davis, 1962, s. 109-113). Łącznie w bazie do końca 2018 roku znajdowało się ponad 6300 publikacji posiadających

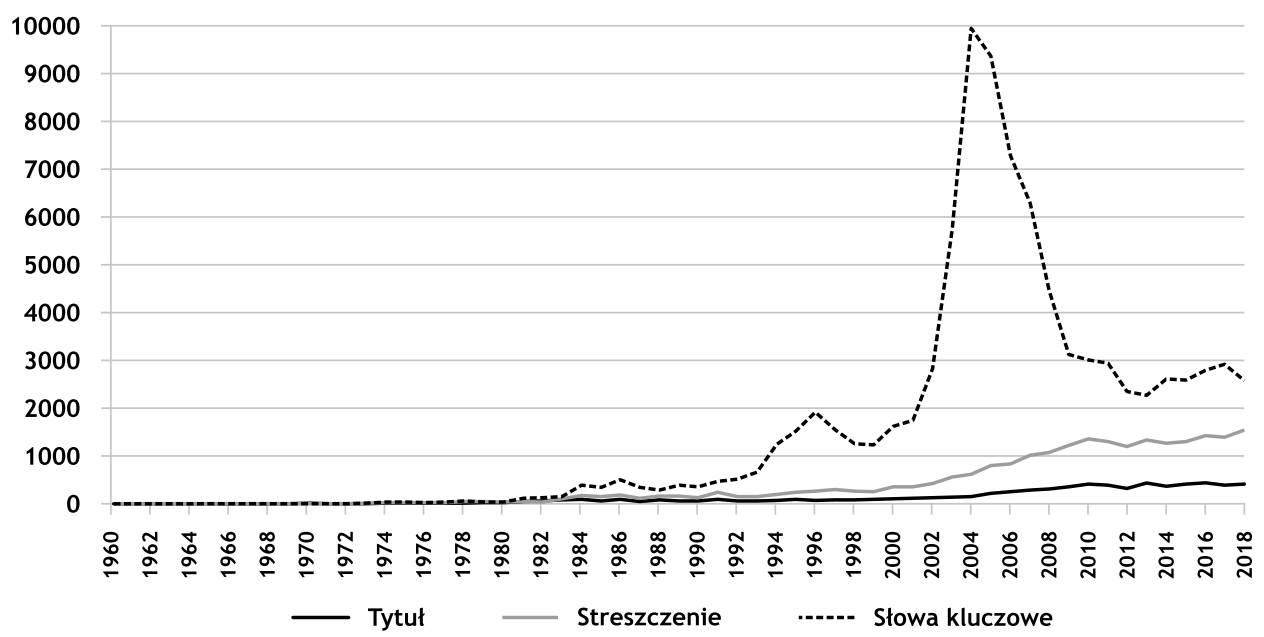

Rys. 1. Liczba publikacji posiadających frazę „project management” w tytule, streszczeniu i stowach kluczowych wedtug bazy Scopus

Źródło: opracowanie własne

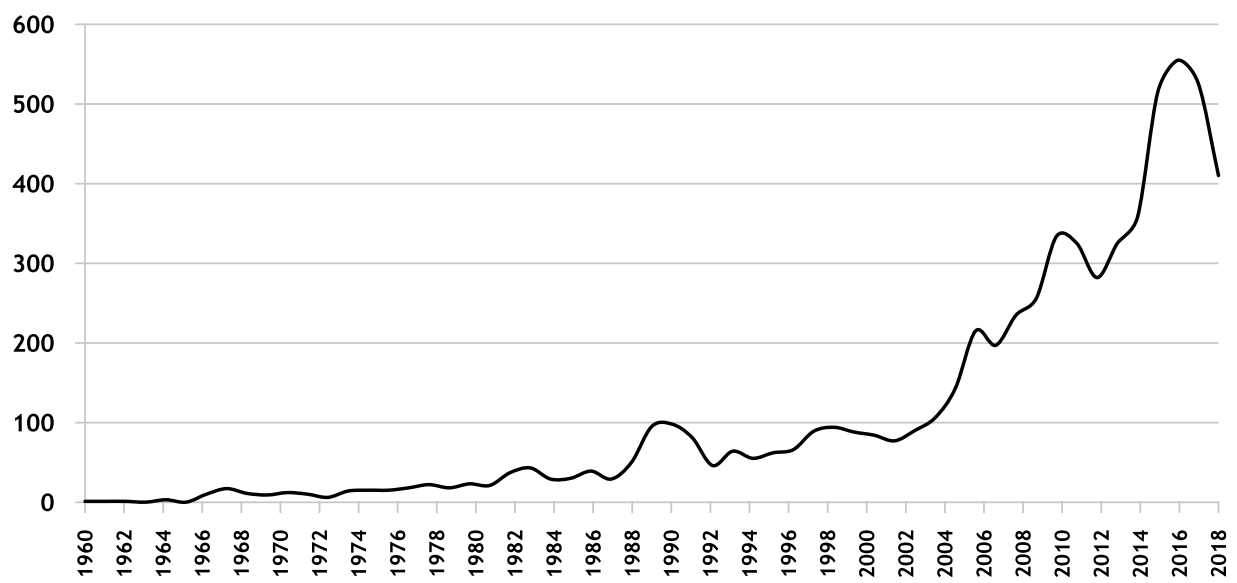

Rys. 2. Liczba publikacji posiadających frazę „project management” w tytule według bazy Web of Science Źródło: opracowanie własne 
frazę „project management” w tytule. Zdecydowany wzrost liczby publikacji dotyczących tego zagadnienia odnotować można w ostatnich latach. Rozkład liczby publikacji w poszczególnych latach przedstawiono na rysunku 2.

3. Ebsco - w związku z brakiem możliwości przeszukania liczby publikacji, biorąc pod uwagę słowa kluczowe, ograniczono analizę do tytułu i streszczenia. Pierwszą publikacją w bazie posiadającą frazę "project management" w tytule jest Project Management Recognizes RéD Performance (Roman, 1964, s. 7-20) z 1964 roku. Jednakże dopiero od lat 90. XX wieku uwidacznia się tendencja wzrostowa liczby publikacji posiadających w tytule tę frazę. Łącznie ponad 5600 takich publikacji znajduje się w bazie. Z kolei w streszczeniu po raz pierwszy ta fraza pojawiła się w publikacji z 1958 roku pt. Weapons System Management (Ramo, 1958, s. 14-19). I jak wynika z rysunku 3, widoczna jest wyraźna tendencja rosnąca publikacji, które w streszczeniu odnoszą się do zarządzania projektami. Do końca 2018 roku było ich ponad 25 tysięcy.
4. Baza Wiley-Blackwell - po raz pierwszy w tej bazie artykuł posiadający frazę "project management" w tytule pochodzi z 1970 roku, a jest to Project Management: Some Current Developments (Yanej, 1970, s. 6-7). Jednakże wzrost liczby publikacji, których tytuł zawierał tę frazę ujawnia się dopiero od roku 2007. Łącznie do końca 2018 roku w bazie znajduje się ponad 1200 publikacji posiadających w tytule frazę zarządzania projektami. Z kolei w streszczeniu fraza "project management” po raz pierwszy pojawiła się w roku 1967 w recenzji publikacji pt. Project Management and Control: Volume II Applied Operational Planning (Martino, 1967a) oraz Project Management and Control: Volume III Allocating and Scheduling Resources (Martino, 1967b). Od tego czasu uwidacznia się stopniowy wzrost liczby publikacji, które zawierają tę frazę w streszczeniu. W sumie $\mathrm{w}$ bazie jest ich ponad 17 tysięcy. W słowach kluczowych natomiast fraza „project management” występuje po raz pierwszy w publikacji z 1981 roku pt. Software Engineering: An Example of Misuse (Fisher, Slonim, 1981). Biorąc pod uwagę dane zawarte w bazie, liczba

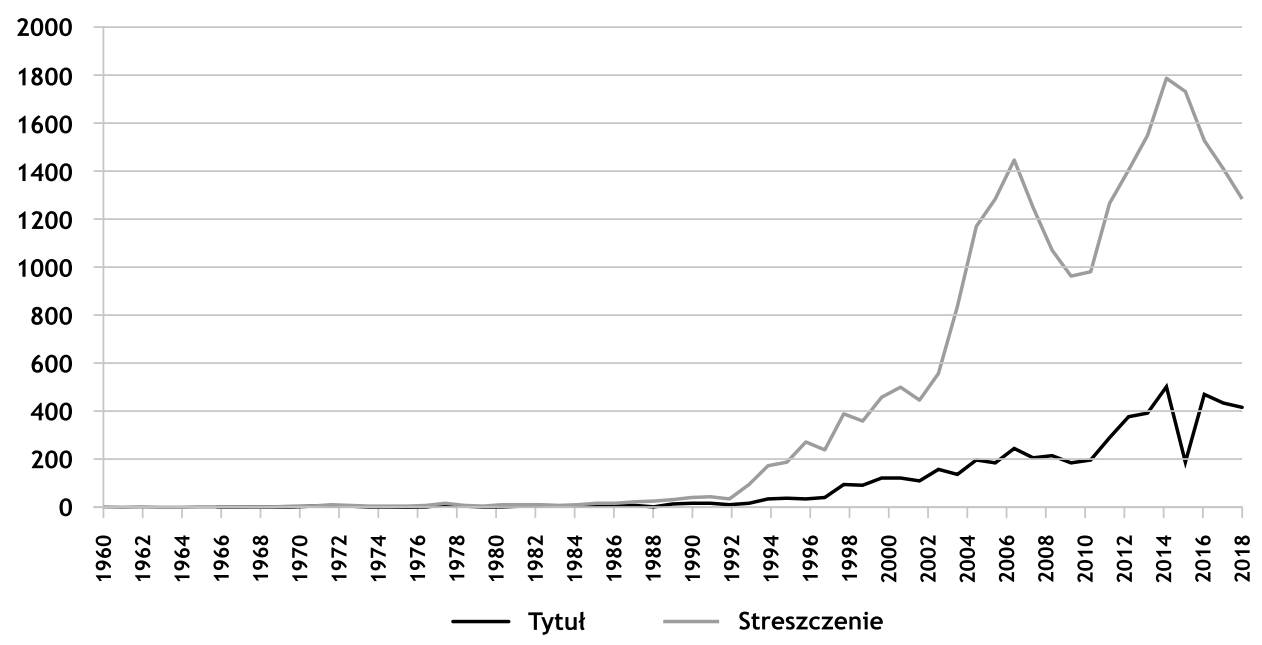

Rys. 3. Liczba publikacji posiadających frazę ,project management” w tytule i streszczeniu według bazy Ebsco

Źródło: opracowanie wtasne

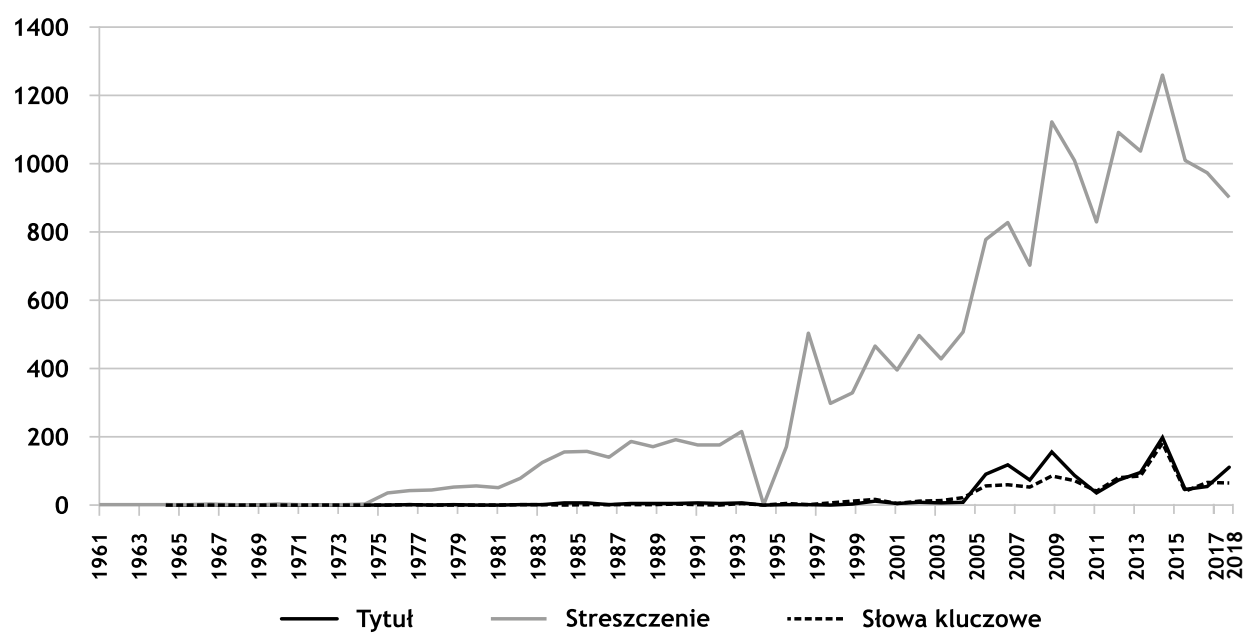

Rys. 4. Liczba publikacji posiadających frazę „project management” w tytule, streszczeniu i stowach kluczowych wedtug bazy Wiley-Blackwell

Źródto: opracowanie wtasne 
publikacji, w których w słowach kluczowych znajduje się to wyrażenie, zwiększyła się od roku 2007. W sumie jest ich około tysiąca. Kształtowanie się liczby publikacji z uwzględnieniem trzech wyżej wymienionych kryteriów pokazanych na rysunku 4.

\section{Tendencje zmian liczby publikacji - analiza porównawcza baz naukowych}

W celu określenia tendencji zmian dokonano porównania pomiędzy bazami liczby publikacji posiadających frazę "project management” odpowiednio w tytule, streszczeniu i słowach kluczowych.

Jak wynika $\mathrm{z}$ rysunku 5, do końca lat 70 . XX wieku liczba publikacji posiadających w tytule frazę "project management” była dość mała i podobnie kształtowała się we wszystkich bazach. W latach 80 . XX wieku ujawnił się znaczny wzrost liczby publikacji, co szczególnie jest widoczne w bazach Scopus i Web of Science. W bazie Ebsco tendencja rosnąca rozpoczęła się w latach 90. XX wieku. W XXI wieku liczba publikacji posiadających w tytule frazę „project management” znacząco wzrosła we wszystkich analizowanych bazach, przy czym w bazach Scopus i Web of Science najwięcej publikacji było w roku 2016, w bazie Ebsco w 2014 roku i w bazie Wiley-Blackwell w 2015 roku. Po tych latach liczba publikacji w poszczególnych bazach zmniejszyła się.

Dokonując analizy rysunku 6 przedstawiającego liczbę publikacji posiadających frazę "project management” w streszczeniu, widać, iż do początku lat 80. XX wieku nie było znaczących zmian. Dopiero mniej więcej od połowy lat 80. liczba publikacji wzrosła zwłaszcza w bazach Scopus i Wiley-Blackwell. W bazie Ebsco wzrost nastąpił w latach 90. XX wieku. Jednakże znaczący wzrost ujawnił się w pierwszej dekadzie XXI wieku we wszystkich bazach, przy czym tendencja rosnąca ujawnia się jedynie w bazie Scopus, gdyż w pozostałych bazach od momentu szczytu, który przypada na rok 2014 w przypadku bazy Ebsco i rok 2015 w przypadku bazy Wiley-Blackwell, nastąpił spadek liczby publikacji posiadających frazę „project management" w streszczeniu.

Dokonując porównania liczby publikacji posiadających fraze „project management” w słowach kluczowych przedstawionych na rysunku 7, wyraźnie widać, iż w przypadku bazy Wiley-Blackwell liczba takich publikacji jest niska i kształtuje się na podobnym poziomie we wszystkich

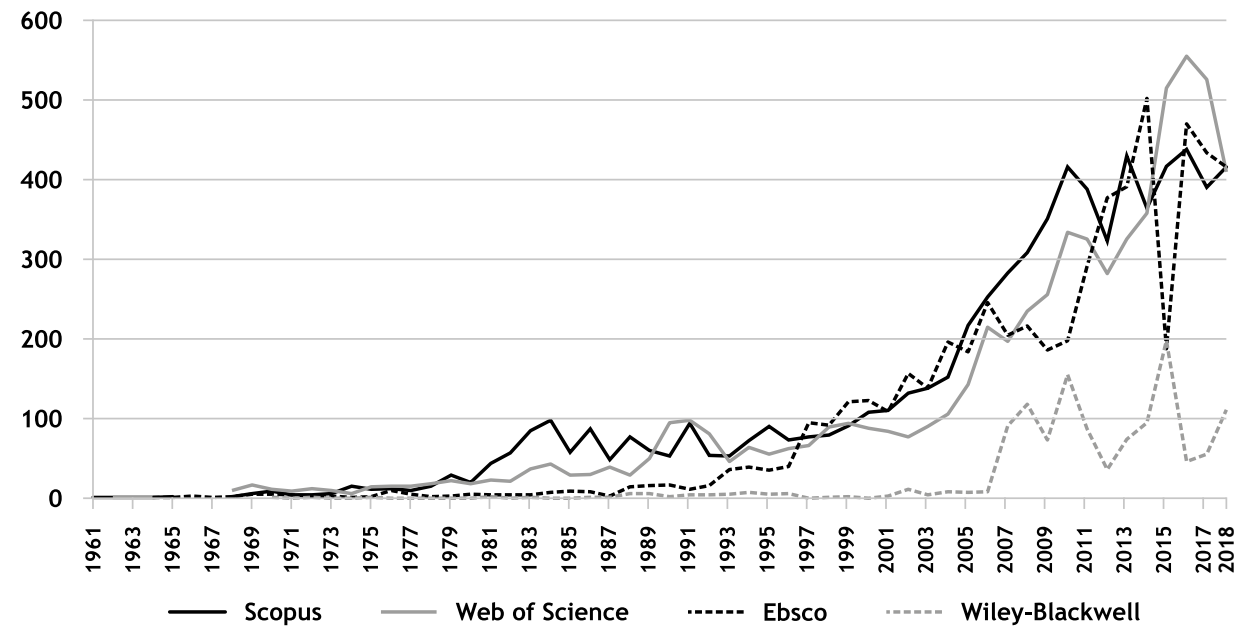

Rys. 5. Liczba publikacji posiadających frazę „project management” w tytule Źródto: opracowanie wtasne

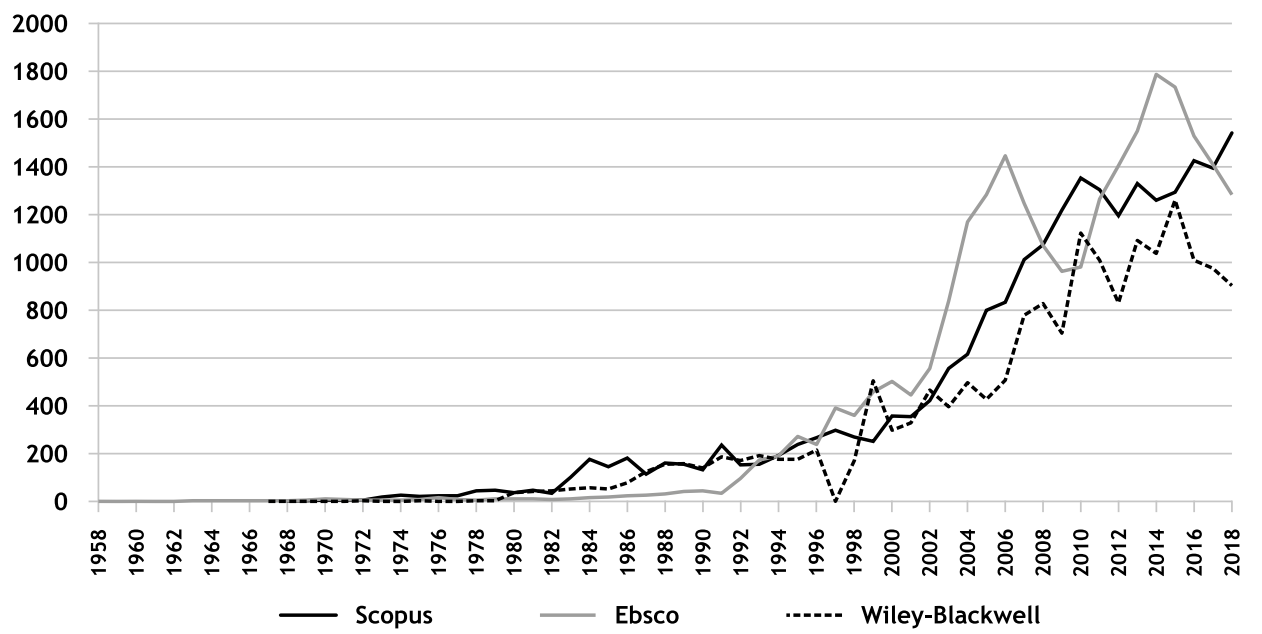

Rys. 6. Liczba publikacji posiadających frazę „project management” w streszczeniu Źródto: opracowanie wtasne 


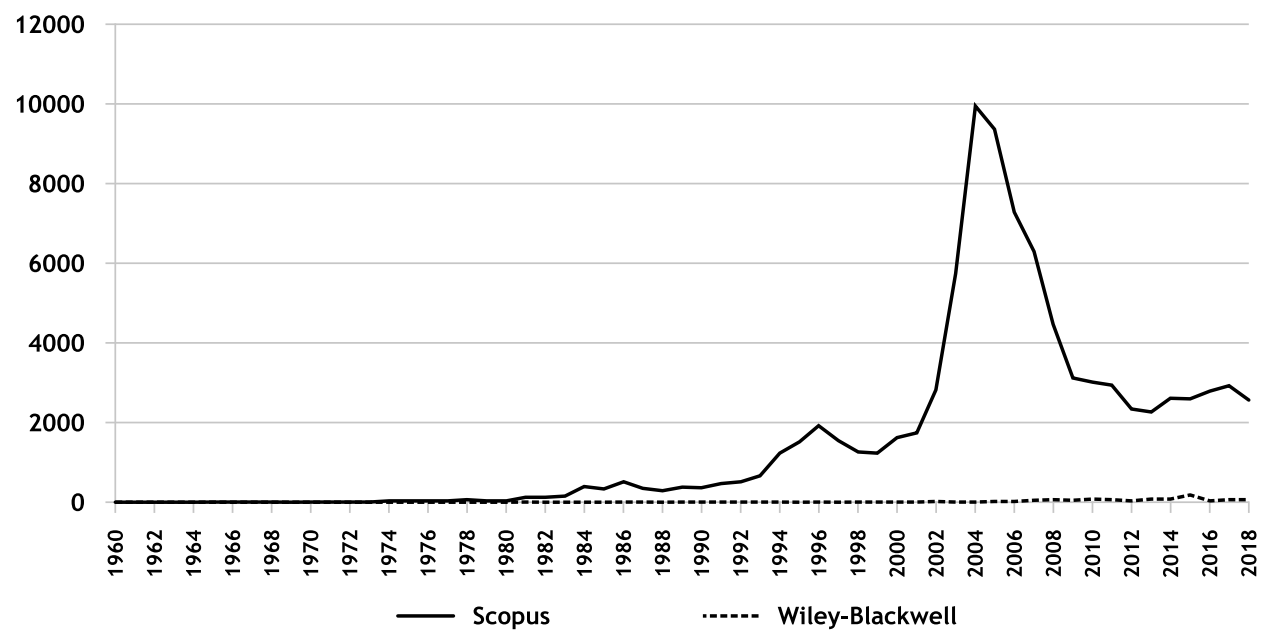

Rys. 7. Liczba publikacji posiadających frazę „project management” w stowach kluczowych Źródto: opracowanie wtasne

latach. Jedynie nieznaczny wzrost odnotowano w 2015 roku. Inaczej natomiast wygląda sytuacja, jeśli weźmie się pod uwagę bazę Scopus. W tym przypadku od lat 80. XX wieku znacząco wzrosła liczba publikacji posiadających frazę „project management” w słowach kluczowych. Jednocześnie widać, iż tendencja rosnąca była do 2004 roku, w którym to roku odnotowano najwięcej publikacji spełniających to kryterium. Po tym roku nastąpiła tendencja malejąca.

Porównując ze sobą wyniki dotyczące liczby publikacji posiadających frazę „project management” odpowiednio w tytule, streszczeniu i słowach kluczowych, wyraźnie widać, iż najwięcej publikacji spełniających te kryteria odnotowano w XXI wieku. Jeśli chodzi o tytuł i streszczenie, to szczyt przypada na lata 2014-2016 w zależności od bazy, a w przypadku słów kluczowych jest to rok 2004. Ogólnie rzecz biorąc, wzrost liczby publikacji w XXI wieku wynika $\mathrm{z}$ faktu, iż do tego okresu literatura dotycząca zarządzania projektami skupiała się $\mathrm{w}$ większości na zadaniach technicznych niezbędnych (w wąskim ujęciu) do osiągnięcia rezultatów projektu. Na początku XXI wieku publikacje podążyły w kierunku znacznie większego zainteresowania zorganizowaniem i skoordynowaniem interakcji między wieloma podmiotami odpowiedzialnymi za realizację tych zadań, optymalnego wykorzystania zasobów czy ku zarządzaniu projektem od strony organizacji pracy. Jak zauważyli A. Abbasi i A. Jaafari (2018, s. 91-102), przeprowadzając analizę bibliometryczną, w przeszłości zarządzanie projektami było ściśle związane ze środowiskiem cywilnym i budowlanym oraz przemysłem obronnym, podczas gdy obecnie jest ono powszechnie stosowane w praktycznie wszystkich sektorach gospodarki, takich jak systemy informatyczne i informacyjne, produkcja (innowacje produktowe), finanse i przemysł usługowy oraz sztuka i kultura (wydarzenia). Ich badania pokazują, że do nowych tematów w dziedzinie zarządzania projektami od 2010 roku należą bezpieczeństwo i zrównoważone zarządzanie.

Przegląd baz pozwolił również wskazać ważniejsze czasopisma z obszaru zarządzania projektami, do których należą: „Project Management Journal”, „International
Journal of Project Management", "International Journal of Managing Projects in Business”, „International Journal of Project Organisation and Management".

W tym miejscu należy również odnieść się do przeglądu literatury przeprowadzonego przez różnych autorów dotyczącego zarządzania projektami, co może stanowić uzupełnienie przedstawionych wyników badań. N. Johnson, T. Creasy i Y. Fan (2015, s. 153-166) przeprowadzili 15-letni przegląd literatury przedstawiający siedem czasopism poświęconych zarządzaniu projektami zawierających 273 artykuły w celu odkrycia pięciu najważniejszych teorii wykorzystywanych przez naukowców zajmujących się tym zagadnieniem. Badanie tych autorów ograniczone było do szukania słów „teoria” lub „teorie” w tytule, streszczeniu lub słowach kluczowych. Ich przegląd pokazał, iż najczęściej wykorzystywanymi teoriami były: teoria zbiorów rozmytych, teoria ograniczeń, teoria aktorów-sieci, teoria interesariuszy i teoria użyteczności. Publikacja, której autorami są W.H. Ramadan oraz Z. Tu (2012), zawiera przegląd literatury dotyczącej praktyk zarządzania projektami i przedstawia obszerną bibliografię oraz klasyfikację w ramach przewodnika PMBOK Guide. Autorzy przeanalizowali 130 artykułów na temat zarządzania projektami opublikowanych w „Project Management Journal” w latach 1997-2011 i podzielili je na dziewięć obszarów wiedzy i pięć grup procesów. Wyniki tego przeglądu wyraźnie pokazują, że planowanie projektu jest najpopularniejszą grupą procesów badawczych, a inicjowanie i zamykanie projektu to zaniedbane tematy badawcze. $\mathrm{W}$ artykule autorstwa P. Svejviga i P. Andersena (2014, s. 278-290) przedstawiono wyniki ustrukturyzowanego przeglądu literatury dotyczącej zarządzania projektami opartego na klasyfikacji i analizie 74 pozycji. Dzięki analizie wyłoniło się łącznie 6 nadrzędnych kategorii, w ramach których można sklasyfikować publikacje. Są to: kontekstualizacja, aspekty społeczne i polityczne, przemyślenie praktyki, złożoność i niepewność, aktualność projektów i szersza konceptualizacja. Y.-W. Huang (2018, s. 217-223) przeprowadziła badanie mające na celu ocenę obecnego rozwoju i trendów badań nad zarządzaniem projektami poprzez analizę bibliometryczną. Aby osiągnąć ten cel, 
w publikacji przeanalizowano 1209 artykułów opublikowanych w okresie obejmującym lata 2008-2017 w dwóch czołowych czasopismach: „International Journal of Project Management” i „Project Management Journal”. Artykuły zostały pobrane z Web of Science, a analiza ilościowa została przeprowadzona, aby dowiedzieć się, którzy autorzy najczęściej publikowali i z jakich krajów pochodzi najwięcej badań. Wyszukano również najbardziej cytowane pozycje za pomocą narzędzia do analizy wizualizacji CiteSpace. Y.-W. Huang zbadała również trendy i najpopularniejsze tematy ostatnich dziesięciu lat. Wyniki analizy pokazują, że najwięcej publikacji pochodzi z Australii, Anglii, USA i Chin, z czego najczęściej cytowane są artykuły pochodzące z Anglii. Najbardziej wpływowymi autorami indywidualnymi lub podmiotowymi w zarządzaniu projektami, którzy byli najczęściej cytowani $\mathrm{w}$ ostatnich latach, są natomiast: PMI, J.R. Turner, A.J. Shenhar, J. Söderlund, L.H. Crawford i K.M. Eisenhardt. W tym miejscu należy również wskazać polskich autorów, którzy wnoszą wkład w rozwój tej subdyscypliny. Należą do nich m.in.: M. Trocki, B. Grucza, J. Kisielnicki, S. Spałek, E. Głodziński i P. Wyrozębski.

Y.-W. Huang (2018, s. 222-223) w swoim artykule wyodrębniła również dziesięć najpopularniejszych trendów, do których należą studium przypadku, praktyka zarządzania projektami, projekt publiczny, badanie taksonomiczne, reakcja organizacji pozarządowych, kontrola portfela projektów, podejmowanie decyzji, kierunek osobowości, rozwój projektu publicznego, portfel projektów i zaangażowanie kierownictwa wyższego szczebla. W analizie bibliometrycznej przeprowadzonej przez A. Abbasi i A. Jaafari (2018, s. 91-102) przy użyciu bazy danych Scopus publikacje zostały wyodrębnione pod względem frazy „zarządzanie projektem” w tytułach lub słowach kluczowych lub streszczeniach i ograniczono się tylko do artykułów w czasopismach opublikowanych w języku angielskim w latach 1980-2017 włącznie. Opracowana przez nich baza danych obejmowała 38 lat badań nad zarządzaniem projektami i składała się z 25784 publikacji z kilku obszarów tematycznych, takich jak: inżynieria, biznes i zarządzanie, informatyka, nauki społeczne, nauki o środowisku, energia, medycyna i chemia. $\mathrm{W}$ analizie autorzy wykluczyli prace z konferencji. Autorzy na podstawie analizy wyników zauważyli, że ewolucja zarządzania projektami w ciągu ostatnich 4 dekad jest odpowiedzią na stale rosnącą złożoność projektów, programów i organizacji. Jest to poparte szybkim wzrostem liczby publikacji i prac naukowych opublikowanych w tej dziedzinie.

\section{Podsumowanie}

A by zbadać stopień popularyzacji w ramach subdyscypliny zarządzania projektami, a także zrozumieć, jak ewoluowała ona w czasie, przeprowadzono badania dotyczące tego, jak zmieniała się liczba publikacji, począwszy od pierwszych znajdujących się w poszczególnych bazach, tj. Scopus, Web of Science, Ebsco i Wiley-Blackwell. Brane tu były pod uwagę publikacje dotyczące zarządzania projektami opublikowane $\mathrm{w}$ języku angielskim we wszystkich dziedzinach, które miały frazę „zarządzanie projektami" odpowiednio w tytule, streszczeniu lub słowach kluczowych. Analiza wybranych baz naukowych jednoznacznie pokazuje wzrost zainteresowania koncepcją zarząadzania projektem w XXI wieku, chociaż w ostatnich latach uwidacznia się raczej tendencja malejąca liczby publikacji o tej tematyce. Wyniki badań pozwoliły także wyodrębnić ważniejsze czasopisma z obszaru zarządzania projektami.

Istotnych informacji dostarczyła również analiza publikacji bibliometrycznych innych autorów. Wskazane tu zostały najważniejsze teorie wykorzystywane przez naukowców zajmujących się zarządzaniem projektami, jak również grupy procesów badawczych. Pokazano również opracowaną klasyfikację publikacji i trendy badań nad zarządzaniem projektami. Przedstawione wyniki różnych badań mogą służyć jako drogowskaz dla badaczy pozwalający ukierunkować ich badania tak, aby znaleźć niewykorzystaną niszę tego obszaru badawczego.

Ograniczeniem interpretacji wyników uzyskanych badań jest fakt, iż prezentowane dane oparte są na wybranych bazach. Wydaje się zasadne przeprowadzenie szerszych badań i bardziej szczegółowej analizy pozycji literatury połączonej z przyporządkowaniem poszczególnych publikacji do wyodrębnionych w ramach badań obszarów zarządzania projektami.

\section{dr Izabela Konieczna \\ Uniwersytet Jana Kochanowskiego w Kielcach \\ Wydział Prawa, Administracji i Zarządzania \\ ORCID: 0000-0002-3632-3245 \\ e-mail: irud@interia.pl}

\section{Bibliografia}

[1] Abbasi A., Jaafari A. (2018), Evolution of Project Management as a Scientific Discipline, „Data and Information Management”, Vol. 2, No. 2, pp. 91-102.

[2] Bowen K.P. (1961), The Martin Company's Project Management Method, SAE Technical Papers, April.

[3] Cleland D.I., Gareis R. (2006), Global Project Management Handbook. Planning, Organizing, and Controlling International Projects, McGraw-Hill, New York.

[4] Davis K. (1962), The Role of Project-management in Scientific Manufacturing, ,IRE Transactions on Engineering Management", Vol. 9, No. 3, pp. 109-113.

[5] Fisher P.S., Slonim J. (1981), Software Engineering: An Example of Misuse, „Software: Practice and Experience”, Vol. 11, No. 6, June.

[6] Haine R.W., Lob W. (1960), The Application of Closed-Loop Techniques to Engineering Project Planning, „IRE Transactions on Engineering Management", Vol. EM-7, No. 3, September, pp. 96-103.

[7] Huang Y.-W. (2018), Project Management Research in IJPM and PMJ: A Bibliometric Analysis, „International Journal of Innovation, Management and Technology", Vol. 9, No. 6, December, pp. 217-223. 
[8] Johnson N., Creasy T., Fan Y. (2015), Fifteen Years of Theory in Project Management: A Review, „International Journal of Construction Project Management", Vol. 7, No. 2, pp. 153-166.

[9] Martino L. (1967a), Project Management and Control: Volume II Applied Operational Planning, „Journal of Management Studies", Vol. 4, No. 1, February.

[10] Martino L. (1967b), Project Management and Control: Volume III Allocating and Scheduling Resources, „Journal of Management Studies", Vol. 4, No. 1, February.

[11] Paton C.R., Kohr R.F., Forester M.A. (1942), Automobile Engineering Organization and Procedure, „SAE Technical Papers", January, pp. 439-443+464.

[12] Prabhakar G.P. (2008), Projects and Their Management: A Literature Review, „International Journal of Business and Management", Vol. 3, No. 9, August, pp. 3-9.

[13] Ramadan W.H, Tu Z. (2012), Project Management Literature: Gaps and Opportunities, E-Leader, Berlin.

[14] Ramo S. (1958), Weapons System Management, „California Management Review", Vol. 1, No. 1, Fall, pp. 14-19.

[15] Roman D.D. (1964), Project Management Recognizes R\&D Performance, „Academy of Management Journal”, Vol. 7, No. 1, March, pp. 7-20.

[16] Svejvig P., Andersen P. (2014), Rethinking Project Management: A Structured Literature Review with a Critical Look at the Brave New World, „International Journal of Project Management”, Vol. 33, No. 2, pp. 178-290.
[17] Trocki M., Bukłaha E. (red.), (2016), Zarzadzanie projektami - wyzwania i techniki badań, Oficyna Wydawnicza SGH, Warszawa.

[18] Yanej J.P. (1970), Project Management: Some Current Developments, „Performance Improvement”, Vol. 9, No. 3, April, pp. 6-7.

\section{Popularization of Project Management Research - Results of Bibliometric Research}

\section{Summary}

The purposes of the article are to determine changes in the popularity of project management topics among researchers and to determine in which journals research in this area is most often published. The implementation of the goal was based on a review of selected scientific databases such as Scopus, Web of Science, EBSCO, and Wiley-Blackwell. The analysis of selected scientific databases clearly shows an increase in interest in the concept of project management in the 21st century, although in recent years one can observe a decreasing trend regarding the number of publications on this subject.

\section{Keywords}

project management, scientific databases 